Stanovsky, D. (1999) "Princess Diana, Mother Teresa, and the Value of Women's Work." NWSA Journal, vol. 11, no. 2: 146-151, Summer 1999. Published on behalf of the National Women's Studies Association by Indiana University Press. (ISSN: 1040-0656)

\title{
Princess Diana, Mother Teresa, and the Value of Women's Work
}

\section{Derek Stanovsky}

\begin{abstract}
Media representations of Princess Diana and Mother Teresa following their deaths extolled their good works and selfless devotion to others. This essay explores these representations using Luce Irigaray's analysis of women's unpaid domestic labor and charity. It argues that there is a connection between the unpaid status of so much of women's work and the current imagery surrounding Princess Diana and Mother Teresa celebrating the capacity of women to perform acts of charity and work for free.
\end{abstract}

\section{ARTICLE}

It is thought to be normal, moral, a sign of good policy, for a woman to receive no payment, or low payment, to be asked to do charity work.

--Irigaray 1993b, 82

The one-year anniversary of the deaths of Princess Diana and Mother Teresa has come and gone, yet public interest and media attention has scarcely flagged. They remain two of the highest-profile women of the decade and have become cherished cultural icons of an ideal and idealized vision of the virtuous woman. This is despite the many striking differences between the young and glamorous Princess of Wales, who married into one of the largest private fortunes in the world and was killed in a high speed car chase through the streets of Paris, and Mother Teresa, a Catholic nun and founder of the Sisters of Charity who spent her long life working among the poorest of the world's poor, lived vows of celibacy and poverty, and died quietly in her Mission in Calcutta at the age of $87 .{ }^{1}$ These two very different women, who lived spectacularly different lives, share a common fate as emblems of feminine virtue for millions around the world. But why this 
unlikely pairing? What, beyond the mere fact that they died within days of each other, accounts for the shared appeal of a nun and a princess?

In her essay, "Women, the Sacred, Money," Luce Irigaray examines the role women play in economies based on sacrifice. She is concerned with the cultural meanings assumed by acts of sacrifice and with the ways in which women, both literally and figuratively, participate in these acts. In particular, Irigaray addresses the role of charity work "in regard to the function of women in a sacrificial society such as our own" and considers how such work is incorporated into both the cultural economy of religion as well as the secular, material economy (1993b, 75). She then examines the range of caring labor that women so often perform, such as the care and feeding of children, and notes the ways in which this work lies along a [End Page 146] continuum with other charitable work, all of which is either unpaid or underpaid and all of which requires women to make sacrifices for others. These connections, between the unpaid, charitable work that women are expected to perform, the sacrifices this entails, and the status, or lack thereof, accorded to women in our society, may help illuminate the reasons behind the massive cultural attachment to Princess Diana and Mother Teresa in the wake of their deaths.

Princess Diana and Mother Teresa were both famous for their public, and highly visible, good works. Mother Teresa devoted her life to aiding lepers, the sick, and the needy in Calcutta and around the world. Princess Diana lent her time and her fame to dozens of charitable causes ranging from those benefitting the victims of AIDS to the victims of land mines. The work these women did was good, important, and worthy of public attention and support but, as is so often the case, their popularity is overdetermined by the underlying causes. There are many who labor at charitable work, yet remain virtually anonymous. To understand the popularity of Princess Diana and Mother Teresa, additional cultural resonances must be explored.

Beyond the fact of the shared good works performed by the two women lies another shared fact that is all but obscured by their contrasting social stations. Both women performed their work for free. The help they rendered was of enormous value, yet it was given freely. This is the meaning of charity. Yet it may be that it is not simply the good, hard, and valuable work Princess Diana and Mother Teresa performed for others that led to their wide-spread appeal, but that they asked nothing for themselves in return for this work that is of most importance. In short, their willingness to sacrifice their time and energy for others and that they did so expecting nothing in return may be more significant than any tangible results their efforts achieved. Coupled with the fact that it was done by women, this willingness to work for free and to devote oneself to the needs of others sends a powerful message that a woman's value may be in direct proportion to the sacrifices she makes.

The reasons enabling Princess Diana and Mother Teresa to work for free were very different. Mother Teresa, by virtue of being a nun and embracing a life of personal poverty, accepted no payment for her services, relying on the Church for her support. Her renunciation of material wealth made possible her charitable works. For Princess 
Diana, just the opposite was true. It was because she was one of the wealthiest women on earth that she was able to work for free. Her financial independence as the Princess of Wales made it possible for her to participate in charitable work as a full-time job. In the one case, the absence of wealth and, in the other, its excess was largely responsible for allowing each to devote her time to such causes.

It is the similarity between this selfless, charitable work and the domestic [End Page 147] caring labor performed by the vast majority of women around the world that lends images of Princess Diana and Mother Teresa their cultural weight. Both types of work are unwaged, and both constitute a sacrifice. Irigaray writes: "When we ask a woman to work for nothing, when we, as women, refuse to accept or seek society's remuneration for our work, that constitutes a repression" (1993b, 81). It is a repression of the value accorded to women as women. It is a repression of the cultural and material resources put at the disposal of women to be used for their own purposes and goals. For Irigaray, a mark of the ubiquity of this repression can be found in the fact that it is seen as so unexceptional, and even expected, that women should not be paid for their work, especially work aimed at taking care of the needs of others. Even more than this, it becomes a sign of virtue on the part of the woman to serve others without pay. Selfsacrifice comes to be a crucial part of what it means to be a good woman. For instance, Irigaray writes: "It is clear that our societies assume that the mother should feed her child for free, before and after birth, and that she should remain the nurse of man and of society" (1993b, 83). This willingness to work for free appears at the core of the role most closely associated with "woman" in our society, that of mother. The idea of a mother who would demand payment for feeding her child is deeply shocking to our cultural sensibilities. However, why should such clearly valuable and necessary work not be compensated? It is here that the full radical potential of a campaign such as International Wages for Housework can be glimpsed. Far from simply working to reinscribe women within the confines of a restrictive domestic economy, the demand for wages for housework may instead strike at the heart of women's oppression by undermining the founding fiction that a woman's worth is based on her willingness to sacrifice herself and to work for free.

There is certainly a history of at least some women receiving some pay for performing some aspects of the caring labor associated with motherhood. This ranges from the disappearing vocation of wet nurse to the emerging, high-tech job of surrogate mother along with a host of more common occupations such as cook, housekeeper, therapist, and prostitute (Wood 1997, 51). However, it is significant that even women who engage in these occupations professionally receive no pay when they perform these tasks in their own homes, for their own families. Mothers always work for free. In the case of Princess Diana and Mother Teresa, what distinguishes them is their willingness to perform some of these same tasks of caring labor for people outside of their immediate families and to render these services for free, that is, as if they were mothers. After all, Teresa, a celibate and childless woman who voluntarily takes on the task of caring for the needy without pay, is awarded the honorific title of "Mother." Here the link between motherhood and all the unpaid caring labor performed by women is made explicit. [End Page 148] 
Continuing her discussion of the unpaid work of motherhood, Irigaray writes:

Who, without irony or unconsciousness, can claim that work and working conditions are justly compensated in the face of the derisory sum a woman can earn for bearing and bringing a child into the world? If this payment did not attest to the tragic distress of many women, it would be the funniest response that could be made in objection to the fair pay issue. Equal pay for equal work? What work? (1993b, n. 5, 84)

So much of "women's work" fails even to count as work that issues of comparable worth cannot be meaningfully raised. What does it mean to demand equal pay for the work of childbirth, a job still performed solely by women? Does it make sense to demand pay equal to that received by men for the same work? Elsewhere, Irigaray poses the question of women's equality as equality with whom? "The demand to be equal presupposes a point of comparison. To whom or to what do women want to be equalized? To men? To a salary? To a public office? To what standard? Why not to themselves?" (1993a, 12). In the case of childbirth, the demand for equal pay is not possible because what is at stake is the acknowledgment of a work specific to women. There is no male standard by which to measure its value. It is the lack of acknowledgment of women's work as work that stands in the way of it being valued, and this is true of all the caretaking and nurturing work women perform and not just that associated with childbirth and childcare.

By and large, the work of meeting the needs of those in crisis falls upon women. It is work that is most often unpaid and with which women must cope using only the resources at hand, resources that are very often insufficient even to meet their own needs. In this context, the labor of caring can only be accomplished through the means of sacrifice. Again, Irigaray writes: "Any women who are content to let other women feed their children on charity and bear children for nothing are (whether voluntarily or not) full participants in a system of values that prizes sacrifice above all" (1993b, 85). Here Irigaray calls attention to the situation where care for oneself and care for others becomes a zero-sum game. Given such a bind, the only options available are ones where aid to others comes at the expense of oneself, where even food for one's children can only be had at the expense of food for oneself. In such a system, care can only be expressed as sacrifice.

It is this system valuing the sacrifices of women that currently celebrates the lives of Princess Diana and Mother Teresa. The images of these women saturating the media are images of compassion and care, of women whose lives were devoted to giving aid and comfort to those suffering. These are stirring and powerful images that, rightly, move and inspire us. It is not necessary to see either Princess Diana or Mother [End Page 149] Teresa as victims in Irigaray's terms. Their lives and their life-choices uniquely suited them to their chosen tasks of providing public services of care and compassion. Mother Teresa through her vows as a nun and Princess Diana through her role as Princess of Wales, and both through their immense personal strength and stamina, chose lives that were not diminished by these duties and demands, but enhanced. However, at the same time as media images praise the accomplishments of 
two extraordinary women, an equally powerful, if more subtle, message is also conveyed, and that message is that it is good for women to work for free and to sacrifice themselves for others. This message resonates with so much in our culture that its truth seems almost self-evident, and implicit in the message is the view that all women should strive to act in this way, not just nuns and princesses.

It should be noted in closing that the tremendous outpouring of public adulation and support for these two was only occasioned by their deaths. It was this overwhelming display of grief that was the final tribute paid by billions around the world to these women. What more graphic testimony to the cultural importance of the sacrifices of women could be imagined than this vast sea of mourning following the final sacrifice enacted by the deaths of Princess Diana and Mother Teresa? What action could more deeply and more permanently mark the value of sacrifice than a willingness to die for others? That this is not what actually happened in no way detracts from the emotional power of such a scenario. Two women, famed for their giving and charity, died. How else can this be understood as anything other than a final act of giving? With an event as fraught with cultural meanings as this, it is unsurprising that the resulting images and representations cannot be consumed uncritically. There are no doubt many progressive possibilities enabled by the fame and popularity of Princess Diana and Mother Teresa. However, the strand of their fame that reinforces the notion that women ought to work for free and be valued for the sacrifices they make for others is one that should be actively resisted.

\section{Note}

1. Biographical information comes from books by Sancton and MacLeod (1998) and by Spink (1997).

\section{References}

Irigaray, Luce. 1993a. Je, Tu, Nous: Toward a Culture of Difference. Trans. Alison Martin. New York: Routledge.

Irigaray, Luce. 1993b. Sexes and Genealogies. Trans. Gillian C. Gill. New York: Columbia University Press.

Sancton, Thomas, and Scott MacLeod. 1998. Death of a Princess. New York: St. Martin's Press.

Spink, Kathryn. 1997. Mother Teresa: A Complete Authorized Biography. New York: Harper Collins. 
Wood, Cynthia A. 1997. "The First World/Third Party Criterion: A Feminist Critique of Production Boundaries in Economics." Feminist Economics, 3(3): 47-68. 